\title{
Economic Growth and Inflation: Evidence from Indonesia
}

\author{
Mas Rangga Cilii ${ }^{*}$, Barkah Alkhaliq ${ }^{2}$ \\ 1, 2Polytechnic APP Jakarta \\ E-mail: ${ }^{1}$ anggacili@gmail.com, ${ }^{2}$ barkah_alkhaliq@yahoo.com
}

*Corresponding author

JEL Classification:

E20

$\mathrm{O} 11$

Received: 22 February 2021

Revised: 08 April 2021

Accepted: 07 May 2021

\begin{abstract}
This study aims to determine the relationship of economic growth with inflation in Indonesia between 2010 and 2014. The research method uses static data panel analysis with economic growth as the dependent variable and inflation, investment, and population as independent variables. Research shows that inflation, investment, and population, where the three variables have the same aim (positive) relationship with economic growth. The effect of investment on economic growth is more significant than inflation on economic growth. The positive relationship between inflation and economic relations shows that inflation can increase economic growth. This can be maintained if the government represented by Bank Indonesia can always keep inflation at a low/mild level. Inflation targeting policy needs to be maintained by referring to the inflation targeting of previous years.
\end{abstract}

\section{Keywords:}

Economic growth, inflation, Indonesia, static panel data analysis

\section{How to Cite:}

Cili, M. R., \& Alkhaliq. (2022). Economic Growth and Inflation: Evidence from Indonesia. Signifikan: Jurnal IImu Ekonomi, 11(1), 145-160. https://doi.org/10.15408/sjie.v11i1.19848. 


\section{INTRODUCTION}

Indonesia, consisting of 13.466 islands with 1.922 .570 miles of land area and 3.257.483 wide miles of water, has become the dust of hope for more than 237 million people (Statistics, 2010). The agrarian country blessed with abundant natural resources has catapulted the populated desire to have a prosperous life. The population welfare can be measured from the GDP per capita of its netizen. Table 1 shows the GDP per capita of Indonesian countries, several ASEAN countries, and China from 2009 to 2012. GDP per capita of Indonesia only remained in a range of $\$ 2100$ to $\$ 3700$. Compared to our neighboring country that is still in one clump, named Malaysia, in a range of $\$ 8400$ to $\$ 10800$, income per capita of Indonesian people is only a third of the income per capita of Malaysian people. GDP per capita of Indonesia is only a bit higher than Vietnam, which is in a range of $\$ 1100$ to $\$ 1700$. In 2012, the Indonesian Central Bureau of Statistics mentioned that the income per capita of Indonesia ranked 102 from 161 countries.

Table 1. GDP Per Capita of Several ASEAN Countries and China (in US\$)

\begin{tabular}{ccccc}
\hline Country & $\mathbf{2 0 0 9}$ & $\mathbf{2 0 1 0}$ & $\mathbf{2 0 1 1}$ & $\mathbf{2 0 1 2}$ \\
\hline Indonesia & $2,262.7$ & $3,125.2$ & $3,647.6$ & $3,700.5$ \\
Malaysia & $7,312.0$ & $9,069.0$ & $10,427.8$ & $10,834.7$ \\
Singapore & $38,577.3$ & $46,570.0$ & $53,121.2$ & $54,577.1$ \\
Vietnam & $1,232.4$ & $1,333.6$ & $1,543.0$ & $1,755.3$ \\
China & $3,800.5$ & $4,514.9$ & $5,574.2$ & $6,264.6$ \\
\hline
\end{tabular}

Source: World Bank

A portrait of the GDP per capita of Indonesia from the period 2009 to 2012 is only a tiny picture of Indonesia's economic growth. From the GDP side, Indonesia, with a large number of residents, can be expected to have a significant income (GDP), as displayed in Table 2. Based on the GDP of ASEAN countries and China above, Indonesia has the biggest GDP among the ASEAN country. With the largest population in the world, China has eight times the GDP of Indonesia. Based on population, in 2015, China had 1,367,485,000 population, while Indonesia had 255,994,000 population (the U.S, 2017), where China's population is five times more than Indonesia's population. For GDP per capita, China is nearly two times larger than Indonesia.

Table 2. GDP of Several ASEAN Countries and China (in Billion US\$)

\begin{tabular}{ccc}
\hline Country & 2011 & 2012 \\
\hline Indonesia & 893.0 & 917.9 \\
Malaysia & 298.0 & 314.4 \\
Singapore & 275.4 & 289.9 \\
Vietnam & 135.6 & 155.8 \\
China & $7,492.4$ & $8,461.6$ \\
\hline
\end{tabular}

Source: World Bank 
The welfare rate cannot be separated from its economic growth. Economic growth is often used as a measuring instrument of a country in managing a long-term and short-term economy. Economic growth shows that economic activities will generate more income for people in a certain period. This was possible because economic activities occur because of factors production to produce an output. Economic growth shows the growth of goods and services produced in an economic area for a specific time (Statistics, 2018). High economic growth will increase society's income (the amount of money circulating will rise), but unfortunately, it is challenging to avoid inflation (The Theory of Quantity).

Today, the conversation about economic growth and the factors that influenced it is being discussed, one of them is inflation. Inflation has become one of the indicators that cannot be ignored in an economy. Since 2000 inflation targeting has been set periodically by the Indonesian government. From 2016 to 2018, the government has issued a Ministry of Finance Regulation (PMK) Number 93/PMK.011/2014 about inflation targeting in 2016, 2017, and 2018. In the Ministry of Finance, Regulation determined that inflation was $4 \%$ in $2016,4 \%$ in 2017 , and $3,5 \%$ in 2018 , each with a deviation of $1 \%$. Regarding inflation targeting, some studies have been done to look at the correct limit of inflation so that inflation would not hamper economic growth (Vinayagathasan, 2013; Risso \& Carrera, 2009; Hwang \& Wu, 2011 ).

Inflation is a tendency of prices to rise in general and continuously. Inflation can have positive implications or negative implications. Boediono (2014), in general, describes the cause of inflation as the following: the first, the amount of money circulating is increasing, whether it demand deposits or a currency, where this condition is known as the theory of quantity. Second, The theory is known as Keynes theory describes that inflation can happen if the demand for goods has exceeded the available amount of goods, or it can be said that people want to live beyond the limits of their abilities.

High inflation can harm an economy. This is why the government has periodically set an inflation target. When inflation is high, prices will increase continuously, the value of currencies decreases, and society tends to dislike cash, followed by decreasing production activity (Nopirin, 2014). However, low inflation will have a benefit for the economy. The rising prices that occur will encourage manufacturers to expand production. The effect of this production expansion will drive positive economic growth. Samuelson $\&$ Nordhaus (2004) said that when inflation is low, the prices will be stable, and society will trust the money because the value of money can be maintained, and the society wants to make a real investment.

Much discussion links the relationship between economic growth and inflation are done. The research discusses that economic growth caused inflation (Hartini \& Utomo, 2004). However, there is also research proving that inflation affects economic growth (Caporin \& Maria, 2002), even there is also research proving that both have a bidirectional causality (Caporale \& Skare, 2011). The cases above indicate that it will always be a controversy whether inflation affects the economic growth or the economic growth that affects inflation, or both are mutually affected. 
This research will discuss one of the controversial elements above: Does inflation affect Indonesia's economic growth? This case is interesting to discuss when Indonesia's inflation is known to always be at a low level after the global economic crisis in 2008, as graphic one shows. Based on the theory, low-level inflation will be helpful to an economy where inflation will drive the society to make a real investment.

Much empirical proof about the effect of inflation on economic growth is produced. In their study about Determinants of Economic Growth: A Cross Country Empirical study Barro (1997) finds that higher inflation is in line with the lower economic growth rate. The research used a Panel Data method with 100 countries from 1960 to 1990 . Research by Caporin \& Maria (2002) entitled Inflation and Growth: panel data evidence empirically analyzed the relationship between inflation and economic growth in 19 countries from 1979 to 1997. The variables used in this research are GDP per capita, inflation, the standard deviation of inflation, consumption expenditure, investment, ongoing foreign investment, foreign debt, school level, and birth rate. This research shows that the effect of inflation on economic growth varies for each country. Fischer (1993), in his research, used a cross-section and regression panel method has found a negative relationship between inflation and economic growth.

Figure 1. Indonesia Consumer Price Index

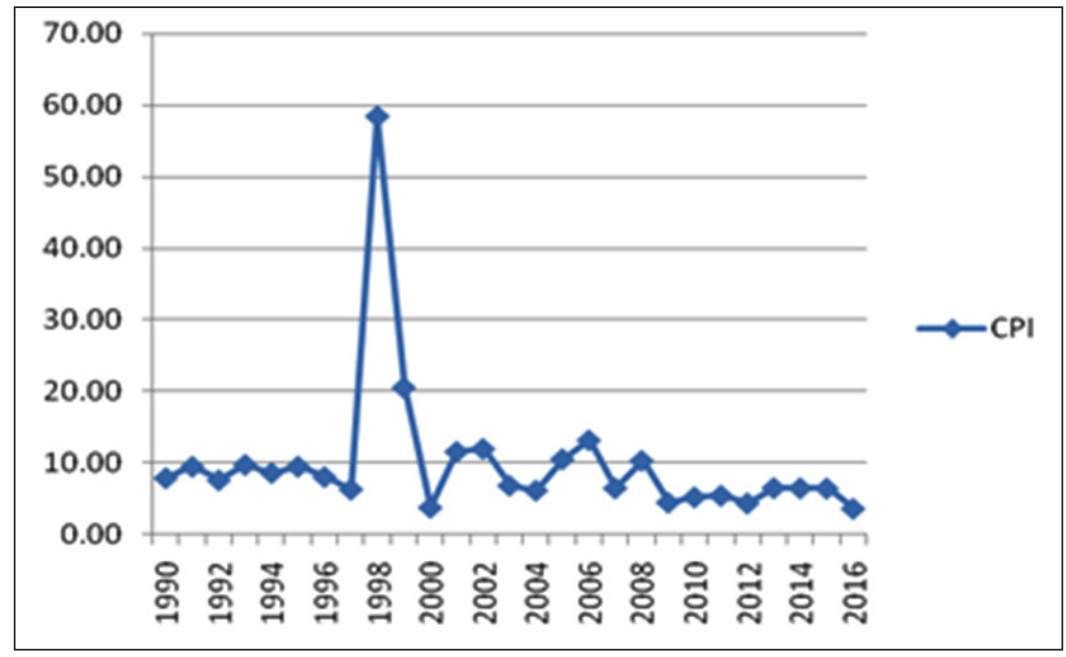

Source: World Bank

Mamo (2012), in his research, try to find the relationship between inflation and the economic growth in sub-Saharan Africa using a panel data analysis and the causality relationship between economic growth and inflation. The dependent variable used in this model is economic growth, and the independent variable is inflation, investment, population, and GDP per capita. This research shows a negative relationship and significance between inflation and economic growth. Besides, research shows that inflation affects economic growth in all sample countries, and economic growth has affected inflation in two countries. Inflation can also predict economic growth in all sample countries, and economic growth can also predict inflation in two sample countries. Azam \& Emirullah 
(2014) do research at nine-country in Asia and the Pacific to know the impact of the inflation rate, corruption, and other variables on GDP per capita. The result stated that inflation rate and corruption are relatively negative significant towards GDP per capita. Risso \& Carrera (2009) research inflation and economic growth in Mexico. The result shows that if inflation is up to $9 \%$, it will hamper economic growth. However, under $9 \%$, inflation does not significantly affect economic growth.

Another research do Mallik \& Chowdhury (2001) find a positive long-term relationship between economic growth and inflation in Bangladesh, India, Pakistan, and Sri Lanka. Munir \& Mansur (2009), in their research about the relationship between inflation rate and the economic growth rate in Malaysia during 1970 - 2005, find if the inflation rate is above the threshold (threshold of inflation), then the economic growth rate will go slow. However, if the inflation rate is under the threshold (threshold of inflation), economic growth has a positive relationship. The same case also happened in Hasanov's (2011) research in Azerbaijan. The research has analyzed the possible effect of threshold inflation on economic growth from 2000 - to 2009. This analysis shows that if the inflation is above the threshold of inflation, there is a negative relationship with economic growth, but if the inflation is under the threshold, then there is a positive relationship with economic growth.

Studies about the impact of globalization and financial development on economic growth in China and India have been done. The result stated that globalization had accelerated the economic growth in India, but in China, the result is different. Globalization is hampering economic growth because globalization has increased export rivalry. Another result is the acceleration of capitalization and inflation as a proxy aggregate request, positively related to economic growth in China and India (Kandil et al., 2017). Studies in Vietnam and China find a tight relationship between money supply growth and inflation. In China, the correlation coefficient is valued as 1 for both variables, yet in Vietnam, the value is 0,991 , and for both countries, the correlation coefficient is positive (Doan Van, 2019). Another study with China as the sample has found that if inflation is up to $2,5 \%$, it will hamper economic growth, but if it is under $2,5 \%$, then inflation would drive economic growth (Hwang \& Wu, 2011).

A positive or negative relationship between inflation and economic growth is the most obtained result in some research for both variables. However, no relationship between inflation and economic growth also had been discovered by some researchers. Vinayagathasan (2013) revealed the relationship between inflation and economic growth in 32 ASIAN countries, and the result shows that if inflation is up to 5,43\%, it will hamper economic growth. However, if inflation is under that limit, it would not have any relationship to economic growth. Manamperi (2014) researches inflation and economic growth in BRICS (Brazil, Russia, India, China, and South Africa) countries. The result shows no long-run relationship between inflation and economic growth in Brazil, Russia, China, and South Africa, but a positive long-run relationship is found in India. A negative short-run relationship is significantly found in Brazil, Russia, China, and South Africa, while a positive short-run relationship is found in India. 
The importance of economic growth and inflation in the economy and the controversy over the relationship between economic growth and inflation are exciting and essential to examine. Previous studies conducted in various countries, including Indonesia, concluded different results on economic growth with inflation. In previous research conducted in Indonesia, the character of each province in Indonesia was not accommodated. The study examines the relationship of economic growth with inflation based on conditions in Indonesia by capturing individual characteristics (provinces in Indonesia) and time, given the very diverse conditions of the various provinces. The static data analysis panel method is used to capture the characteristics of the province and the time.

\section{METHODS}

This research uses secondary data from the Indonesian Central Bureau of Statistics and the Indonesian Investment Coordinating Board. The data refer to economic growth data, inflation, investment, and the population. The data type used in this research is panel, time-series, and cross-section. Time series data are obtained from 2010 to 2014, and the cross-section data includes 33 provinces in Indonesia.

In this research, the variable of economic growth is the dependent variable. Data used here is the value of Gross Regional Domestic Product (GRDP) based on the constant introductory price of 2000, with the Indonesian Central Bureau of Statistics as the source of data. Inflation is the independent variable and the focus of this research. By definition, inflation tends to rise in general and continuously-Source of data by Indonesian Central Bureau of Statistics. The variable of investment is the independent variable. Data used in this research is the value of foreign investment (PMA), with the Indonesian Investment Coordinating Board as the data source. The variable of the number of populations is the independent variable. The population data is used here, with the Indonesian Central Bureau of Statistics as the data source.

Using this panel data enables us to observe based on individual and time characteristics. This panel data can accommodate the variable of heterogeneity which is not put in a model (unobserved individual heterogeneity), able to reduce the collinearity between variable and the estimate on panel data able to minimize the refraction produced by the individual aggregation because the data unit are increasing (Baltagi, 2005).

Panel data are form by merging of time series data and cross section data, so it can be made by this equation:

$$
\mathrm{Y}_{\mathrm{it}}=\alpha+\beta \mathrm{X}_{\mathrm{it}}+\varepsilon_{\mathrm{it}}
$$

$\mathrm{i}=1,2, \ldots \ldots, \mathrm{N}$;

$\mathrm{t}=1,2, \ldots . ., \mathrm{T}$

$\mathrm{i}=\mathrm{i}$ individual

$\mathrm{t}=\mathrm{t}$ of the period

N.T: increasing of panel data 
There are two analysis methods used in this panel data: static panel data analysis and dynamic panel data analysis. This research uses static panel data analysis as the analysis method. Three approaches are generally used in static panel data: Pooled Least Square, Fixed Effect Model (FEM), and Random Effect Model (REM). In FEM and REM, both of them can be differentiated based on the assumption of whether there is a correlation between the error component with the independent variable (regressor) (Firdaus, 2011).

Chow test is used to determine which method will be used between pooled least square and fixed-effect model. The Chow test must be conducted first to determine all the approaches above. If the result of this test showed the fixed effect model better, then the Hausman test has to be done next. The Hausman test determines which method we should use between the fixed and random effects. Hausman test is required to see whether there is a correlation between regressor and the personal effect or not. The relationship between the variables above can be seen in the following equation:

$$
\operatorname{lnPEit}=\alpha_{0}+\alpha_{1} \mathrm{INF}_{\mathrm{it}}+\alpha_{2} \operatorname{lnINV}_{\mathrm{it}}+\alpha_{3}+\mathrm{JPEN}_{\mathrm{it}}+\varepsilon_{\mathrm{it}}
$$

Where

$\operatorname{lnPE}_{\mathrm{it}} \quad$ : Constant Gross Regional Domestic Product (GRDP) province in the $t$ year (Million Rupiah)

INF : Inflation of $\mathrm{i}$ province in $\mathrm{t}$ year (in percentage)

ln INV : PMA value foreign investment of i province in $\mathrm{t}$ year (Million US\$)

JPEND : Amount of population of $\mathrm{i}$ province in $\mathrm{t}$ year (Thousand)

\section{RESULT AND DISCUSSION}

The relationship between economic growth and inflation in Indonesia is interesting to be noticed, especially with the use of panel data which can control the heterogeneity of individuals. The sample of this data is taken from 33 provinces in a range of 2010 to 2014. The first test we should do is the Chow test. This test compares which model is better between the PLS model and the FEM model.

Table 3. Chow Test

\begin{tabular}{cccc}
\hline Effects Test & Statistic & d.f & Prob \\
\hline Cross-section F & 408.538159 & $(32,1290)$ & 0.0000 \\
Cross-section chi-square & 763.674113 & 32 & 0.0000 \\
\hline
\end{tabular}

Table 3 shows the result of the Chow test, using the actual level of $(\alpha)=10 \%$ has obtained the result of Probability (Prob) is 0.0000 . So, we can conclude that the result of the Chow test is to receive $\mathrm{H}_{1}$. Thus, at this stage, the obtained result is that Fixed Effect Model (FEM) is better than Pooled Least Square (PLS) model. The next stage is to select whether to use a Fixed Effect Model (FEM) or Random Effect Model (REM). This test will be done using the Hausman test. 
Based on the Hausman test in Table 4, where the comparing is done between Fixed Effect Model (FEM) and Random Effect Model (REM), has obtained the result of Probability (Prob) is 0.0000 . Using the actual level of $(\alpha)=10 \%$, the Prob is $<0$, so the result of this test is receiving $\mathrm{H}_{1}$. This case means that Fixed Effect Model (FEM) is the most appropriate model to use. This model will be used in this research.

Table 4. Hausman Test

\begin{tabular}{cccc}
\hline Test Summary & Chi-Sq. Statistic & Chi-Sq. d.f & Prob \\
\hline Cross-section random & 25.043031 & 3 & 0.0000 \\
\hline
\end{tabular}

The coefficient of determination or Goodness of Fit indicates whether the estimation of that model is good or not. After receiving which model is the most appropriate, the regression is due by that model/equation. Table 5 shows the regression result; coefficient of determination $\left(\mathrm{R}^{2}\right)$ valued 0.997121 . The value of $\mathrm{R}^{2}$ reflects how much the variation of the dependent variable (PE) can be described by the independent variable (INF, INV, JPEND) (Nachrowi \& Hardius, 2006). If $\mathrm{R}^{2}$ approaches 0 , the dependent variable (PE) cannot be described by the independent variable (INF, INV, JPEND). If $\mathrm{R}^{2}$ approaches 1 , the more the dependent variable $(\mathrm{PE})$ can be described by the independent variable (INF, INV, JPEND).

The coefficient of determination in this research showed the value is approaching 1 , and this described that 99,7\% variation of the variable PE (GRDP) could be described by INF variable (inflation), INV (investment), and JPEND (the amount of population). The rest of $0,3 \%$ can be described by variables outside the model. In Table 5 can be seen that all of the independent variables, inflation (INF), investment (log INV), and the amount of population (JPEND), are positively influenced to economic growth (log $\mathrm{PE}$ ) as dependent variables on $\alpha=10 \%$. This case means that inflation is increasing if the economic growth increases. If the investment is increasing, then the economic growth increases. If the amount of population is increasing, the economic growth also increases.

Table 5. Fixed Effect Model

\begin{tabular}{cccc}
\hline Independent Variable & Coefficient & Value of Statistic T & Probability \\
\hline INF & 0.010229 & 3.433142 & 0.0008 \\
LOG(INV) & 0.034449 & 4.179711 & 0.0001 \\
JPEND & 0.00016 & 5.522857 & 0.0000 \\
C & 15.89592 & 79.42931 & 0.0000 \\
R-squared & 0.997121 & & \\
Adjusted R-squared & 0.99634 & & \\
\hline
\end{tabular}


In their research, the positive relationship between inflation and economic growth is also found in Mallik \& Chowdhury (2001). They find a positive relationship between inflation and economic growth in Bangladesh, India, Pakistan, and Sri Lanka. They describe that in this condition, what economic policy needs to do is seek economic growth that is consistent with stable inflation. Munir \& Mansur (2009), Hasanov (2011), and Hwang \& $\mathrm{Wu}$ (2011), in their research, also find a positive relationship between inflation and economic growth. However, this positive relationship is only happening when inflation is under the threshold of inflation that the government has set. Based on this finding, the government is being proposed to keep inflation under the threshold of inflation that has been set. In general, these two research results show that keeping inflation at a low/light rate is essential.

The value of the coefficient on each variable can be interpreted as the following: The coefficient on the variable of inflation rate (INF) amounted to 0,0102 means that every $100 \%$ increase in the inflation rate will affect the economic growth to increase by $1,02 \%$. The coefficient on investment variable (log INV) amounted to 0,034 means that every $100 \%$ increase in investment will increase economic growth by $3,44 \%$. The coefficient on the variable of the number of population (JPEND) amounted to 0,00016 means that every 100 thousand population increase will affect the economic growth by $0,016 \%$.

The theory can explain the positive relationship between the three variables with economic growth that low inflation will encourage a reasonable price increase, so that producer will expand production (investment), which leads to economic growth. The number of inhabitants as a multiplier is based on its growth. The estimation results also show that investment in economic growth $(0,03)$ is more significant than inflation's effect on economic growth $(0,01)$.

\section{Overview of Economic Growth}

From 2010 to 2014, almost 33 provinces positively impacted GRDP economic growth, showing stable economic growth in almost all provinces. Based on the region, Java island made an enormous contribution to GRDP. As shown in Table 6, Java island gave a stable economic contribution in 5 years as big as $\pm 57 \%$. This result was mainly contributed by manufacturing, construction, and retail trade activities supporting Java Island as the economic center. Maluku-Papua islands gave the lowest contribution, as much as $\pm 2 \%$, although those islands have the most mining and quarrying activity. Sumatera island provides the second-largest contribution, is known to have a relatively vast agricultural land, plantations, and forests gave a stable contribution of around $22 \%$. This contribution was donated by the Agricultural-Forestry-Fishing sector, Manufacturing and Mining quarrying.

The research results of Akinlo et al. (2020) state that the agriculture sector can contribute to economic growth in Nigeria. It is suspected that the value chain in the agricultural sector in Nigeria has given multiple players an effect on the manufacturing, 
pharmacy, and ICT services sector, which in turn increases the export of agricultural products in addition to exports of crude oil. The study results in Nigeria are fascinating to observe when juxtaposed with conditions in Indonesia. Different economic activities in different provinces or islands in Indonesia contribute to GRDP. Economic activity in Maluku-Papua Island, namely Mining-quarrying, while in Sumatera Island, namely Agriculture-Forestry-Fishing, Manufacturing, and Mining-quarrying, has contributed very differently to GRDP. The difference in the contribution to the GRDP can be observed from the value chain side of each developing sector in the area.

Table 6. Percentage of GRDP on Big Islands in Indonesia

\begin{tabular}{|c|c|c|c|c|c|}
\hline Islands & 2010 & 2011 & 2012 & 2013 & 2014 \\
\hline Sumatera & 22,39 & 22,39 & 22,31 & 22,15 & 22,03 \\
\hline Jawa & 57,28 & 57,40 & 57,51 & 57,69 & 57,90 \\
\hline Bali \& Nusa Tenggara & 3,03 & 2,93 & 2,87 & 2,88 & 2,90 \\
\hline Kalimantan & 9,41 & 9,44 & 9,40 & 9,24 & 9,06 \\
\hline Sulawesi & 5,19 & 5,31 & 5,45 & 5,55 & 5,64 \\
\hline Maluku \& Papua & 2,70 & 2,53 & 2,46 & 2,50 & 2,48 \\
\hline
\end{tabular}

Source: Indonesian Central Bureau of Statistics

Mining-Quarrying activities in Maluku-Papua only stop on raw materials explorations. As for Agriculture-Foresty-Fishing activities in Sumatera are continuing into manufacturing. This case could be seen in Table 7, which serves percentage data of GRDP Distribution by Island and Sector. The 17 data groups only serve three-sector data: Agriculture-Foresty-Fishing sector, Mining-Quarrying sector, and Manufacturing sector. It can be seen that the most significant economic activity in Maluku island - Papua is the Mining and Quarrying sector that takes 33,3\%, but the manufacturing sector only takes 9,8\%. Exploration on the Mining Sector that is not continued with processing only gives a bit advantage to the economy because this Mining commodity will be exported by their raw form (ores/concentrates), which only give a bit of economic value-added. Constitution No. 4 of 2009 about Mining of Mineral and Coal enforced since January 12, 2014, mandates that mining products like gold, iron ore, nickel, coal have to go through value-adding/downstream before being exported. Ika (2017) proves that the potentiality of increasing revenue can be realized from value-adding policy/downstream the non-renewable mineral resources.

In Sumatera, the dominant economic activity is the Agriculture-Foresty-Fishing sector that is $23,3 \%$, and the manufacturing sector $20 \%$. The raw material that results from the Agriculture-Foresty-Fishing sector is processed from the manufacturing sector. Value-adding/downstream on Agriculture-Foresty-Fishing sector could be seen in the manufacturing sector developing in those areas. Saragih (2018) said that most 
of the manufacturing industry in Sumatera island is based on agro-industry, oil, and natural gas.

Table 7. Average Percentage of GRDP Distribution by Island and Industry

\begin{tabular}{lccc}
\hline \multirow{2}{*}{ Islands } & \multicolumn{3}{c}{ Sector } \\
\cline { 2 - 4 } & $\begin{array}{c}\text { Agriculture, Forestry, and } \\
\text { Fishing }\end{array}$ & $\begin{array}{c}\text { Mining and } \\
\text { Quarrying }\end{array}$ & Manufacturing \\
\hline Sumatera & 23,258 & 15,56 & 20,416 \\
Jawa & 8,272 & 2,404 & 29,55 \\
Bali \& Nusa Tenggara & 21,304 & 7,104 & 4,98 \\
Kalimantan & 11,616 & 38,188 & 18,418 \\
Sulawesi & 26,28 & 8,504 & 10,668 \\
Maluku \& Papua & 14,054 & 33,288 & 9,79 \\
\hline
\end{tabular}

Source: Indonesian Central Bureau of Statistics

\section{Overview of Inflation Policy}

Bank of Indonesia (BI) since 2005 embraced the Inflation Targeting Framework (ITF) by using interest rate as the operational monetary target, as previously used base money as their operational monetary target. In its journey, ITF applied as the flexible ITF. This is based on a lesson taken by the 2008 finance global crisis, where the central bank needs the flexibility to anticipate monetary problems.

\section{Inflation and Economic Growth}

Inflation and GRDP 2010 - 2014 on the main island of Indonesia were interesting to scrutinize. Based on Table 8 inflation rate of the island outside of Java, in general, was more significant than the inflation rate in Java island. The unbalance of supply and demand has caused a high inflation rate in the region outside of Java island. This condition on those islands increases their requirements on electricity, fuel, transportation, communication, housing, food, and others. High demand on some expenditure groups, such as housing group, water, electricity and fuel, transportation group, communication, financial services, food and beverage group, cigarette and tobacco group, and clothing group, has a significant effect on inflation rate outside of Java island. Sumatera island, Kalimantan and Bali - Nusa Tenggara donating a high inflation rate. This can be understood by their high Agriculture, Forestry and Fishing, Mining quarrying activities in Sumatera and Kalimantan, and Bali - Nusa Tenggara is the tourism center.

The supply limitation can be seen in how much the logistic cost is needed to the region outside of Java island. A Logistics system that has not been efficient was causing a considerable amount of additional fees to some commodities or products to be moved from their production place into their consumer (Trade, 2013). One of the domino effects of the inefficient logistics system is the expensive fuel outside Java island. 
Unfortunately, fuel has become the main requirement for investment and tourism, such as Sumatera, Kalimantan, Bali, and Nusa Tenggara. These days government has made strive fuel's policy into one price throughout Indonesia. This was made in 2016 by issuing ESDM ministerial regulation No. 36 of 2016, and the implementation started in January 2017.

Table 8. Inflation on Big Islands in Indonesia

\begin{tabular}{lccccc}
\hline \multicolumn{1}{c}{ Islands } & $\mathbf{2 0 1 0}$ & $\mathbf{2 0 1 1}$ & $\mathbf{2 0 1 2}$ & $\mathbf{2 0 1 3}$ & $\mathbf{2 0 1 4}$ \\
\hline Sumatera & 8,3 & 4,0 & 3,7 & 8,8 & 8,9 \\
Jawa & 6,6 & 3,4 & 4,2 & 8,0 & 8,2 \\
Bali \& Nusa Tenggara & 8,7 & 5,3 & 4,8 & 8,2 & 7,5 \\
Kalimantan & 8,4 & 5,1 & 5,7 & 7,8 & 8,0 \\
Sulawesi & 5,8 & 3,7 & 5,0 & 6,6 & 8,5 \\
Maluku \& Papua & 6,2 & 3,3 & 4,9 & 8,3 & 8,7 \\
\hline
\end{tabular}

Source: Indonesian Central Bureau of Statistics

\section{Investment and Economic Growth}

The report issued Board (2017), as shown in Table 9 was, indicated a high investment rate on Java island, Sumatera and Kalimantan. This was following the enormous GRDP contribution of Java island, Sumatera, and Kalimantan to economic growth. The manufacturing sector dominated the investment in Java island, mainly by motor vehicle industry and other transportation equipment, metal, machinery, electronics industry, paper and printing industry, textile industry, rubber, plastics industry, chemical and pharmaceutical industry, and food industry.

Table 9. Percentage of Investment Value on Big Islands in Indonesia

\begin{tabular}{lccccc}
\hline \multicolumn{1}{c}{ Islands } & $\mathbf{2 0 1 0}$ & $\mathbf{2 0 1 1}$ & $\mathbf{2 0 1 2}$ & $\mathbf{2 0 1 3}$ & $\mathbf{2 0 1 4}$ \\
\hline Sumatera & 4,61 & 11,43 & 15,18 & 11,88 & 13,53 \\
Jawa & 70,91 & 67,86 & 55,61 & 60,64 & 54,31 \\
Bali \& Nusa Tenggara & 3,10 & 5,25 & 4,59 & 3,11 & 3,49 \\
Kalimantan & 12,40 & 10,57 & 13,06 & 9,55 & 16,06 \\
Sulawesi & 5,30 & 3,94 & 6,13 & 5,24 & 7,23 \\
Maluku \& Papua & 3,67 & 0,96 & 5,43 & 9,57 & 5,37 \\
\hline
\end{tabular}

Source: Indonesian Investment coordinating Board

Java island as the economic center has advantages by having various complete infrastructure. The availability of electricity, big roads, airport, port complete with their support equipment, and adequate network telecommunication became attractive by an investor to build investment in Java island. As Sumatera and Kalimantan were rich 
in their natural resources, Sumatera and Kalimantan island were the most significant production areas of palm oil, rubber, coal in Indonesia, where Indonesia is one of the biggest producers palm oil, rubber, and coal globally.

\section{Total Population and Economic Growth}

The population amount could become an opportunity or threat to a country. Indonesia has a large population, trying to make its population an asset. Results of the research (Table 5) show that population amount in Indonesia had a positive influence on economic growth. This condition was related to the demographic bonus. The production side and consumption side could see the demography bonus. Demography bonus in the production side, explained that productive age being the booster on developing the industrialization. However, in Indonesia, a demography bonus on the production side could not be relied upon as the crutch of economic growth. Demography bonus on the consumption side, showing a new middle class with a high consumption rate, could drive economic growth. According to Jati (2015), in Indonesia, economic growth was being pushed by a demography bonus on the consumption side.

\section{CONCLUSION}

Research about the relationship between economic growth and inflation rate in Indonesia is carried out by using the panel data of 33 provinces. Data are obtained by combining the cross-data section and time data series, so it is expected to make the estimated parameter more accurate. After the research, the result can be concluded as the following: economic growth is influenced significantly by inflation, investment, and the amount of population, where the relationship between the three of them have the same aim (positive) with the economic growth. Besides, the result also shows that the influence of investment on economic growth is more significant than inflation's influence on economic growth.

The economic growth could be influenced by economic activity developed in those regions. Sumatera island contributes a large enough on GDRP, developing the AgricultureForestry-Fishing sector and manufacturing sector. High inflation occurs in a region that has unbalanced supply and demand conditions. In those regions, the demand for primary needs secondary and tertiary needs are high but not sustained by adequate supply. A high logistics charge causes this inadequate supply.

The results of this study indicate that inflation can encourage economic growth. When inflation is low, prices will be stable, and people will trust money because its value can be maintained to be motivated to invest in the real sector. Therefore, the government needs to continue to maintain the stability of inflation at a low/light level. Inflation stability at a low/light level can be applied through the inflation targeting policy. The government must continue to evaluate the inflation targeting set in previous years so that inflation can be used to drive the economy. 


\section{REFERENCES}

Akinlo, T., Ekperiware, M. C., \& Olomu, M. O. (2020). Agricultural sector value chain and government policy in Nigeria: issues, challenges, and prospects. African Journal of Economic and Management Studies, 11(3), 525-538. https://doi.org/10.1108/ AJEMS-03-2019-0103

Azam, M., \& Emirullah, C. (2014). The role of governance in economic development: Evidence from some selected countries in Asia and the Pacific. International Journal of Social Economics, 41(12), 1265-1278. https://doi.org/10.1108/IJSE-11-20130262

Baltagi, B. H. (2005). Econometric Analysis of Panel Data 3rd. New York: John Wiley \& Sons, LTD.

Barro, J. . (1997). Determinants of Economic Growth: A Cross-Country Empirical Study. In NBER Working Paper (Vol. 5698). Academic Press. https://doi.org/10.1006/ JCEC.1998.1532

Boediono. (2014). Ekonomi Moneter (Monetary Economics) (17th ed.). BPFE-Yogyakarta.

Caporale, G. M., \& Skare, M. (2011). Employment Growth, Inflation and Output Growth: Was Phillips Right? Evidence from a Dynamic Panel. Ssrn, 11. https:// doi.org/10.2139/ssrn.1898553

Caporin, M., \& Maria, C. Di. (2002). Inflation and growth: some panel data evidence. GRETA Workin Paper, 2(9). http://consulting.greta.it/wp/02.09.PDF

Doan Van, D. (2019). Money Supply and Inflation Impact on Economic Growth. Journal of Financial Economic Policy, 12(1), 121-136. https://doi.org/10.1108/JFEP-102018-0152

Firdaus, M. (2011). Aplikasi Ekonometrika Untuk Data Panel Dan Time Series (Econometrics Application For Panel Data And Time Series). IPB Press.

Fischer, S. (1993). The Role Of Macroeconomic Factors In Growth (NBER Working Paper, Issue 4565). https://wwhttps//www.nber.org/papers/w4565

Hartini, D., \& Utomo, Y. P. (2004). Analisis Pengaruh Inflasi Terhadap Pertumbuhan Ekonomi di Indonesia dengan Metode Final Prediction Error (Analysis of The Effect of Inflation on Economic Growth in Indonesia by Final Prediction Error Method). Jurnal Ekonomi Pembangunan, 5(1), 42-49. doi: https://doi.org/10.23917/ jep.v5i1.4030

Hasanov, F. (2011). Relationship between inflation and economic growth in Azerbaijani economy: is there any threshold effect? (MPRA Paper). University Library of Munich, Germany. https://econpapers.repec.org/RePEc:pra:mprapa:33494

Hwang, J., \& Wu, M. (2011). Inflation and Economic Growth in China: An Empirical Analysis. China \& World Economy, 19(5), 67-84. https://doi.org/10.1111/j.1749124X.2011.01259.x 
Ika, S. (2017). Kebijakan Hilirisasi Mineral: Reformasi Kebijakan untuk Meningkatkan Penerimaan Negara (Mineral Downstream Policy: Policy Reform to Increase State Revenue). Kajian Ekonomi \& Keuangan, 1(1), 42-67. https://doi.org/10.31685/ kek.v1i1.259

Jati, W. R. (2015). Bonus Demografi Sebagai Mesin Pertumbuhan Ekonomi: Jendela Peluang atau Jendela Bencana di Indonesia? (Demographic Bonus as an Engine of Economic Growth: Window of Opportunity or Window of Disaster in Indonesia?). Populasi, 23(1), 1-19. https://jurnal.ugm.ac.id/populasi/article/view/8559/6591

Kandil, M., Shahbaz, M., Mahalik, M. K., \& Nguyen, D. K. (2017). The Drivers of Economic Growth in China and India: Globalization or Financial Development? International Journal of Development Issues, 16(1), 54-84. https://doi.org/10.1108/ IJDI-06-2016-0036

Mallik, G., \& Chowdhury, A. (2001). Inflation and economic growth: evidence from four south Asian countries. Asia-Pacific Development Journal, 8(1), 123-135.

Mamo, F. T. (2012). Economic Growth and Inflation A panel data analysis [Sodertorns University].

Manamperi, N. (2014). The Short and Long-Run Dynamics Between Inflation and Economic Growth in BRICS. Applied Economics Letters, 21 (2), 140-145. https:// doi.org/10.1080/13504851.2013.844318

Munir, Q., \& Mansur, K. (2009). Non-linearity between inflation rate and GDP growth in Malaysia. Economics Bulletin, 29(3), 1551-1565.

Nachrowi, N. D., \& Hardius, U. (2006). Ekonometrika Untuk Analisis Ekonomi dan Keuangan (Econometrics For Economic and Financial Analysis). Depok: Fakultas Ekonomi Universitas Indonesia.

Nopirin. (2014). Ekonomi Moneter Buku 2 (Monetary Economics Book 2). BPFE: Yogyakarta.

Risso, W. A., \& Carrera, E. J. S. (2009). Inflation and Mexican Economic Growth: Long-Run Relation and Threshold Effects. Journal of Financial Economic Policy, 1(3), 246-263. https://doi.org/10.1108/17576380911041728

Samuelson, P. A., \& Nordhaus, W. D. (2004). Ilmu Makro Ekonomi (Macroeconomics) (Edisi 17). New York: McGraw-Hill.

Saragih, J. P. (2018). Kinerja Industri Manufaktur di Provinsi-Provinsi Sumatera Tahun 2010-2015 (Manufacturing Industry Performance in Sumatera Provinces in 20102015). Jurnal Ekonomi \& Kebijakan Publik, 9(2), 131-146. https://doi.org/https:// doi.org/10.22212/jekp.v9i2.747

Trade, M. of. (2013). Kajian Pengembangan Indikator Kinerja Logistik Indonesia (Study of Development of Indonesian Logistics Performance Indicators). http://bppp.kemendag. go.id/media_content/2017/08/Kajian_Pengembangan_Indikator_Kinerja_Logistik_ Indonesia_Final.pdf 
Vinayagathasan, T. (2013). Inflation and economic growth: A dynamic panel threshold analysis for Asian economies. Journal of Asian Economics, 26, 31-41. https://doi. org/10.1016/j.asieco.2013.04.001 